\title{
EVALUASI STANDAR PELAYANAN MINIMUM DAN TINGKAT KEPUASAN PENUMPANG DI TERMINAL ANGKUTAN UMUM TAWANG ALUN JEMBER
}

\author{
Kevin Muzammil $^{* 1}$, Dewi Junita Koesoemawati ${ }^{2}$ dan Willy Kriswardhana ${ }^{2}$ \\ 1 Mahasiswa, Program Studi S-1 Teknik Sipil, Universitas Jember \\ 2 Dosen, Jurusan Teknik Sipil, Universitas Jember \\ kevinmuzammil@gmail.com
}

\begin{abstract}
ABSTRAK
Terminal Tawang Alun Jember merupakan Terminal Penumpang Tipe A yaitu terminal yang berfungsi untuk melayani transportasi umum baik skala nasional maupun skala internasional. Tujuan penelitian ini adalah untuk mengetahui kepuasan dan harapan dari pengguna jasa terhadap fasilitas dan pelayanan dengan melihat kelengkapan fasilitas di terminal Tawang Alun berdasarkan Peraturan Menteri Nomor 40 Tahun 2015. Evaluasi tingkat kepuasan pelanggan menggunakan acuan berdasarkan Peraturan Menteri Pendayagunaan Aparatur Negara Dan Reformasi Birokrasi Republik Indonesia Nomor 14 Tahun 2017 khususnya mengenai fasilitas utama maupun fasilitas penunjang. Adapun analisis tingkat kepuasan menggunakan metode IPA (Importance Performance Analysis). Berdasarkan hasil pengamatan, tingkat pelayanan adalah sebesar 50,00\% dimana Terminal Tawang Alun memenuhi 28 indikator dari total 56 indikator yang terdapat dalam Peraturan Menteri Nomor 40 Tahun 2015. Tingkat kepuasan dengan melihat unsur pelayanan di Terminal Tawang Alun bernilai 51,31 yang masuk dalam kategori nilai D (Tidak Baik). Nilai tingkat kepuasan digambarkan dalam diagram kartesius yang menunjukkan prioritas utama untuk peningkatan pelayanan adalah pelayanan kelengkapan informasi jadwal keberangkatan bus pada ruang tunggu, tersedia media layanan pengaduan, ketersediaan fasilitas khusus dan toilet khusus penyandang difabel \& lansia, ketersediaan fasilitas khusus ruang ibu menyusui dan tersedia informasi pelayanan yang lengkap.
\end{abstract}

Kata Kunci : Terminal, standar pelayanan, tingkat kepuasan

\section{PENDAHULUAN}

Terminal menurut merupakan prasarana angkutan tempat kendaraan umum mengambil dan menurunkan penumpang dan atau barang [1], tempat perpindahan penumpang dan atau barang dari moda angkutan yang satu ke moda angkutan yang lain yang terjadi akibat tuntutan efisiensi angkutan. Penelitian ini akan membahas mengenai Evaluasi Standar Pelayanan Minimum dari Terminal Tawang Alun yang dikategorikan sebagai terminal kelas A [2]. Evaluasi Terminal Tawang Alun diukur dari tingkat kepuasan pelanggan. Dalam mengevaluasi tingkat kepuasan pelanggan, penelitian ini menggunakan Peraturan Menteri Pendayagunaan Aparatur Negara dan Reformasi Birokrasi Republik Indonesia Nomor 14 Tahun 2017 tentang Pedoman
Penyusunan Survei Kepuasan Masyarakat Unit Penyelenggara Pelayanan Publik sebagai acuan penilaian [3], khususnya mengenai fasilitas utama maupun fasilitas penunjang. Metode yang digunakan adalah metode IPA (Importance Performance Analysis), dengan tujuan mengukur hubungan antara pendapat atau kesan konsumen dan tingkat prioritas peningkatan kualitas produk/jasa [4][5].

\section{TINJAUAN PUSTAKA}

\subsection{Standar Pelayanan Minimum}

Standar pelayanan minimum Terminal Penumpang merupakan pedoman bagi penyelenggara terminal atau penyedia jasa angkutan jalan dalam memberikan pelayanan jasa kepada seluruh pengguna jasa terminal yang bertujuan untuk mencapai tingkat 
pelayanan terminal yang optimal [6]. Berdasarkan perturan tersebut, yang wajib disediakan oleh penyelenggara jasa terminal angkutan antara lain pelayanan keselamatan, pelayanan keamanan, pelayanan kehandalan/ keteraturan, pelayanan kenyamanan, pelayanan kemudahan/ keterjangkauan,

\subsection{Teori Kepuasan Pelanggan}

Kepuasan dapat mencerminkan penilaian seseorang tentang kinerja produk dalam kaitannya dengan ekspektasi [7]. Kualitas pelayanan merupakan ukuran dari kinerja dari sebuah perusahaan atau penyedia jasa. Untuk meningkatkan kualitas pelayanan suatu penyelenggara pelayanan publik maka perlu adanya Survei Kepuasan Masyarakat (SKM). Survei Kepuasan Masyarakat merupakan pengukuran secara komprehensif tentang kepuasan masyarakat atau pengguna jasa terhadap pelayanan dari penyedia jasa (PERMENPANRBRI Nomor 14, 2017). SKM mempunyai beberapa indikator atau unsur unsur penilaian, antara lain persyaratan, sistem, mekanisme dan prosedur, waktu penyelesaian, biaya/ tarif, produk spesifikasi jenis pelayanan, kompetensi pelaksana, perilaku pelaksana, penanganan pengaduan, saran dan masukan, sarana dan prasarana. Penilaian unsur diatur dalam skala likert penilaian seperti yang dijelaskan pada Tabel 1.

Tabel 1. Skala likert penilaian

\begin{tabular}{ccccc}
\hline $\begin{array}{c}\text { Nilai } \\
\text { Persepsi }\end{array}$ & $\begin{array}{c}\text { Nilai Interval } \\
(\mathrm{Ni})\end{array}$ & $\begin{array}{c}\text { Nilai Interval Konversi } \\
(\mathrm{Nik})\end{array}$ & $\begin{array}{c}\text { Mutu Pelayanan } \\
\text { Kinerja Unit } \\
\text { Pelayanan (Y) }\end{array}$ & $\begin{array}{c}\text { Tidak baik } \\
2\end{array}$ \\
\hline $1,00-2,5996$ & $25,00-64,99$ & $\mathrm{D}$ & Kurang baik \\
3 & $3,0644-3,532$ & $76,61-88,30$ & B & Baik \\
4 & $3,5324-4,00$ & $88,31-100,00$ & A & Sangat baik \\
\hline
\end{tabular}

Sumber: PERMENPANRBRI Nomor 14, 2017.

\section{$\bar{Y}$ Kepentingan}

\begin{tabular}{|l|l} 
Prioritas Utama & Pertahankan Kinerja \\
A & B \\
\hline Prioritas Rendah & \multicolumn{2}{|c}{ Berlebihan } \\
C & D \\
\hline \multicolumn{2}{l}{$\bar{X}=$ Kinerja / kepuasan }
\end{tabular}

Gambar 1. Diagram kartesius analisis tingkat kepuasan dan kepentingan [9]

Analisis tingkat kepuasan dengan metode IPA (Importance Performance Analysis). Teknik IPA menggabungkan ukuran kepuasan pelanggan yang dirasakan dan kepentingan menjadi plot dua dimensi untuk memudahkan interpretasi data [8]. Metode ini digunakan dengan tujuan untuk mengukur tingkat kepuasan pelanggan terminal Tawang. Setelah didapatkan nilai rata - rata tingkat kepuasan pelanggan, kemudian nilai tersebut diplot pada diagram kartesius seperti pada Gambar 1.

Adapun keterangan masing - masing kuadran dapat dijelaskan dalam keterangan di bawah berikut :

1. Kuadran A (Prioritas Utama)

Menunjukkan indikator ini penting yang dapat mempengaruhi kepuasan pelanggan Terminal Tawang Alun, namun kinerja Terminal Tawang Alun belum sesuai dengan keinginan pelanggan sehingga mengecewakan.

2. Kuadran B (Pertahankan Prestasi)

Menunjukkan indikator penting kinerja Terminal Tawang Alun yang telah berhasil dicapai dengan kondisi sangat penting dan sangat memuaskan. 
3. Kuadran C ( Prioritas Rendah )

Menunjukkan indikator yang kurang penting bagi Pelanggan Terminal Tawang Alun dan dianggap kurang penting dan kurang memuaskan.

4. Kuadran D ( Berlebihan )

Menunjukkan indikator yang tidak begitu penting dalam pemenuhan tingkat kepuasan. Tetapi pelanggan Terminal Tawang Alun menerima pelayanan lebih dari apa yang diharapkan sehingga tidak menjadi prioritas perbaikan [9]

\section{METODOLOGI}

\subsection{Rencana Penelitian}

Dalam tahap ini, dilakukan beberapa kegiatan untuk pengumpulan data, antara lain :

1. Pengamatan langsung yang kemudian menilai fasilitas dan pelayanan dari Terminal Tawang Alun dengan standar pelayanan minimum berdasarkan Peraturan Menteri Perhubungan Republik Indonesia : PM 40 tahun 2015.

2. Penyebaran form Kuesioner kepada penumpang yang akan berangkat, maupun yang sudah datang. Form Kuesioner berisi beberapa pertanyaan dan pernyataan yang menilai fasilitas dan pelayanan Terminal Tawang Alun.

Metode penelitian ini menggunakan metode kualitatif. Metode ini sering disebut metode penelitian naturalistik karena penelitiannya dilakukan pada kondisi alamiah [10].

\subsection{Populasi dan Sampel}

Target wawancara dan reponden dari kuisioner merupakan calon maupun yang telah menjadi penumpang bus tanpa memperhatikan tujuan perjalanan dari penumpang. Dalam menentukan jumlah responden tersebut didapatkan dari data jumlah penumpang bus AKAP di Satuan Pelayanan Terminal Tipe A Tawang Alun Jember pada tanggal 20 - 30 September 2018. Berdasarkan data tersebut didapatkan jumlah populasi sebanyak 10458 penumpang. Penentuan jumlah responden (sampel) ditentukan menggunakan rumus Slovin:

$$
\begin{aligned}
& \mathrm{n}=\frac{\mathrm{N}}{\left(1+\mathrm{Ne}^{2}\right)} \\
& \mathrm{n}=\frac{10458}{\left(1+\left(10458 \times 0.05^{2}\right)\right.}
\end{aligned}
$$

$$
\mathrm{n}=385 \text { orang } \approx 390 \text { orang }
$$

Dengan $\mathrm{n}=$ ukuran sampel, $\mathrm{N}=$ ukuran populasi, dan e $=$ presentasi kelonggaran akibat kurangnya ketelitian dalam mengambil sampel [11].

\subsection{Uji Validitas dan Reliabilitas}

Uji validitas item adalah uji statistik yang digunakan guna menentukan seberapa valid suatu item pertanyaan mengukur variabel yang diteliti. Dalam penelitian ini menggunakan program bantu analisa statistik dengan korelasi Bivariate Pearson (Produk Momen Pearson). Jika $r$ hitung $>r$ tabel, maka instrumen atau item-item pertanyaan atau variable yang diuji berkorelasi signifikan terhadap skor total (dinyatakan valid). Sedangkan uji reabilitas yang berfungsi untuk mengukur seberapa jauh pengukuran bebas dari varian kesalahan acak. Suatu kuisioner dapat dikatakan reliabel atau handal jika jawaban seseorang terhadap pernyataan adalah konsisten atau stabil dari waktu ke waktu. Program bantu analisa statistik memberikan fasilitas untuk mengukur realibilitas dengan uji statistik Cronbach Alpha $(\alpha)$ [12].

\section{PEMBAHASAN}

\subsection{Analisis Standar Pelayanan Minimum}

Terminal Tawang Alun atau sejak awal tahun 2017 menjadi Satuan Pelayan Terminal Tipe A Tawang Alun terletak di Jalan Dharmawangsa, Desa Kaliwining, Rambipuji, Jember. Terminal Tawang Alun terklasifikasi sebagai terminal tipe kelas A (Peraturan Daerah Kabupaten Jember No. 1 tahun 2015). Penilaian terhadap kinerja standar pelayanan minimum dari terminal Tawang Alun dilakukan dengan observasi secara langsung terhadap fasilitas yang ada di terminal tawang alun, kemudian dari hasil observasi tersebut disesuaikan berdasarkan Peraturan Menteri Nomor 40 Tahun 2015. Berdasarkan observasi terhadap standar pelayanan minimal dari terminal Tawang Alun Jember, kemudian dikalkulasi, sehingga didapatkan hasil penilaian dalam Tabel 2.

Dari data pada Tabel 2, dapat disimpulkan bahwa kondisi tingkat pelayanan masih sebesar 50,00\%. Nilai tersebut didapatkan dari rekapan total 56 indikator yang terdapat dalam SPM menurut Peraturan 
Menteri Nomor 40 tahun 2015.

Tabel 2. Rekapitulasi hasil penelitian berdasarkan SPM

\begin{tabular}{cccc}
\hline & Total & Indikator & Tingkat \\
Pelayanan & Indikator & Terpenuhi & Pelayanan \\
& & & $(\%)$ \\
\hline Keselamatan & 10 & 5 & $8,93 \%$ \\
Keamanan & 3 & 1 & $1,79 \%$ \\
Kehandalan / & 6 & 2 & $3,57 \%$ \\
Keteraturan & & & \\
Kenyamanan & 18 & 11 & $19,64 \%$ \\
Kemudahan / & & & $14,29 \%$ \\
Keterjangkauan & 15 & 28 & $50,00 \%$ \\
Kesetaraan & 4 & & \\
\hline Total & 56 & & $1,79 \%$ \\
\hline
\end{tabular}

Dari keseluruhan fasiltas yang ada, Terminal Tawang Alun hanya memenuhi 28 indikator. Berdasarkan hasil pengamatan kinerja fasilitas dan pelayanan dari Terminal Tawang Alun, yang kemudian disesuaikan dengan Peraturan Menteri Nomor 40 Tahun 2015 tentang Standar Pelayanan Penyelenggaraan Terminal Penumpang Angkutan Jalan, didapatkan bahwa beberapa fasilitas dari Terminal Tawang Alun yang sudah sesuai dengan standar. Namun beberapa fasilitas dan pelayanan masih belum memenuhi dan perlu untuk ditingkatkan, seperti tidak tersedianya jadwal keberangkatan dan daftar PO bus, tidak tersedianya keteraturan dari loket penjualan tiket, belum ada aksesbilitas berupa tinggi platform yang sama dengan tinggi lantai bus, dan ruang khusus ibu menyusui juga belum tersedia di Terminal Tawang Alun.

\subsection{Uji Validitas dan Reliabilitas}

Berdasarkan hasil analisis statistik dari 390 responden didapat nilai $r$ tabel sebesar 0,083 . Sementara itu, nilai $r$ hitung yang didapatkan lebih besar dari nilai $r$ tersebut. Sehingga kuisioner yang diajukan merupakan kuisioner yang valid. Sedangkan untuk uji reabilitas didapatkan nilai Cronbach Alpha $(\alpha)$ sebesar 0,746. Nilai tersebut berada pada range $0,60-0,80$. Baik tingkat kepuasan dan kepentingan yang mana berarti kuisioner ini memiliki tingkat reliabilitas yang reliabel dalam analisis data.

\subsection{Analisis Tingkat Kepuasan Menurut Peraturan Menteri}

Analisis ini bertujuan untuk mengukur tingkat kepuasan pelanggan terhadap fasilitas atau standar pelayanan yang ada di terminal Tawal Alun berdasarkan Peraturan Menteri Pendayagunaan Aparatur Negara Dan Reformasi Birokrasi Republik Indonesia Nomor 14 Tahun 2017. Berdasarkan hasil analisis diapatkan hasil dalam Tabel 3.

Tabel 3. Unsur - unsur penilaian

\begin{tabular}{|c|c|c|c|c|c|}
\hline NO & & UNSUR PELAYANAN & NILAI & KUMULATIF & KET \\
\hline $\mathrm{X} 1$ & $=$ & $\begin{array}{c}\text { Ketersediaan Jalur Pejalan kaki yang tidak menimbulkan } \\
\text { Crossing dengan jalur kendaraan }\end{array}$ & 2.26 & 56.5385 & Tidak Baik \\
\hline $\mathrm{X} 2$ & $=$ & $\begin{array}{c}\text { Pelayanan yang ramah serta selalu siap memberikan } \\
\text { informasi kepada penumpang }\end{array}$ & 2.44 & 61.0256 & Tidak Baik \\
\hline $\mathrm{X} 3$ & $=$ & $\begin{array}{c}\text { Petugas cepat tanggap dalam menanggapi keluhan yang } \\
\text { disampaikan pelanggan. }\end{array}$ & 2.34 & 58.4615 & Tidak Baik \\
\hline $\mathrm{X} 4$ & $=$ & $\begin{array}{l}\text { kelengkapan informasi jadwal keberangkatan bus pada } \\
\text { Ruang Tunggu }\end{array}$ & 1.70 & 42.5641 & Tidak Baik \\
\hline $\mathrm{X} 5$ & $=$ & Tersedia Media Layanan Pengaduan & 1.83 & 45.7692 & Tidak Baik \\
\hline X6 & $=$ & Keamanan yang terjaga di Terminal Tawang Alun & 2.29 & 57.2436 & Tidak Baik \\
\hline $\mathrm{X} 7$ & $=$ & Keyamanan pada ruang tunggu keberangkatan & 2.19 & 54.7436 & Tidak Baik \\
\hline
\end{tabular}




\begin{tabular}{|c|c|c|c|c|c|}
\hline NO & & UNSUR PELAYANAN & NILAI & KUMULATIF & KET \\
\hline $\mathrm{X} 8$ & $=$ & $\begin{array}{l}\text { Ketersediaan fasilitas khusus dan toilet khusus penyandang } \\
\text { difabel \& lansia }\end{array}$ & 2.02 & 50.4487 & Tidak Baik \\
\hline $\mathrm{X} 9$ & $=$ & Ketersediaan fasilitas khusus ruang ibu menyusui & 1.43 & 35.6410 & Tidak Baik \\
\hline $\mathrm{X} 10$ & $=$ & Kebersihan toilet di Terminal Tawang Alun & 2.08 & 51.9231 & Tidak Baik \\
\hline $\mathrm{X} 11$ & $=$ & $\begin{array}{c}\text { Kebersihan Tempat } \begin{array}{c}\text { peribadatan di Terminal Tawang } \\
\text { Alun }\end{array}\end{array}$ & 2.31 & 57.6282 & Tidak Baik \\
\hline $\mathrm{X} 12$ & $=$ & Tersedia Informasi Pelayanan yang lengkap & 1.75 & 43.7179 & Tidak Baik \\
\hline
\end{tabular}

Nilai pada Tabel 3 merupakan nilai unsur yang didapatan dari total rekapitulasi nilai per - unsur kemudian nilai per - unsur tersebut dibagi dengan total responden (390) orang. Setelah didapatkan nilai unsur tersebut, dikalikan angka 25 yang mana merupakan nilai dasar menurut Peraturan Menteri Pendayagunaan Aparatur Negara Dan Reformasi Birokrasi Republik Indonesia Nomor 14 Tahun 2017. Setelah dikalkulasi, didapatkan penilaian terhadap keseluruhan unsur pelayanan yang ada di terminal Tawang
Alun sebesar 51.31 yang mana nilai tersebut masuk dalam kategori nilai D (Tidak Baik).

\subsection{Analisa Tingkat Kesesuaian dan Kesenjangan}

Kesenjangan antara kepuasan dan kepentingan merupakan selisih dari nilai yang didapatkan dari pelanggan tentang kepuasan terhadap fasilitas di terminal Tawang Alun dan nilai kepentingan yang diharapkan. Seperti yang dijelaskan pada Tabel 4.

Tabel 4. Tingkat kesesuaian dan kesenjangan

\begin{tabular}{|c|c|c|c|c|c|c|c|}
\hline \multirow{2}{*}{ NO } & \multirow{2}{*}{ INDIKATOR VARIABEL } & \multicolumn{2}{|c|}{ NILAI TOTAL } & \multirow{2}{*}{$\mathrm{X}_{\mathrm{i}}$} & \multirow{2}{*}{$\mathrm{Y}_{\mathrm{i}}$} & \multirow{2}{*}{$\begin{array}{l}\text { TKi } \\
(\%)\end{array}$} & \multirow{2}{*}{ GAP } \\
\hline & & KEPUASAN & KEPENTINGAN & & & & \\
\hline 1 & $\begin{array}{c}\text { Ketersediaan Jalur Pejalan kaki } \\
\text { yang tidak menimbulkan Crossing } \\
\text { dengan jalur kendaraan }\end{array}$ & 882 & 1263 & 8.82 & 12.63 & 69.8 & -3.81 \\
\hline 2 & $\begin{array}{l}\text { Pelayanan yang ramah serta selalu } \\
\text { siap memberikan informasi kepada } \\
\text { penumpang }\end{array}$ & 952 & 1230 & 9.52 & 12.3 & 77.4 & -2.78 \\
\hline 3 & $\begin{array}{l}\text { Petugas cepat tanggap dalam } \\
\text { menanggapi keluhan yang } \\
\text { disampaikan pelanggan. }\end{array}$ & 912 & 1191 & 9.12 & 11.91 & 76.6 & -2.79 \\
\hline 4 & $\begin{array}{c}\text { kelengkapan informasi jadwal } \\
\text { keberangkatan bus pada Ruang } \\
\text { Tunggu }\end{array}$ & 664 & 1305 & 6.64 & 13.05 & 50.9 & -6.41 \\
\hline 5 & $\begin{array}{c}\text { Tersedia Media Layanan } \\
\text { Pengaduan }\end{array}$ & 714 & 1250 & 7.14 & 12.5 & 57.1 & -5.36 \\
\hline 6 & $\begin{array}{c}\text { Keamanan yang terjaga di Terminal } \\
\text { Tawang Alun }\end{array}$ & 893 & 1221 & 8.93 & 12.21 & 73.1 & -3.28 \\
\hline 7 & Keyamanan pada ruang tunggu & 854 & 1259 & 8.54 & 12.59 & 67.8 & -4.05 \\
\hline
\end{tabular}




\begin{tabular}{|c|c|c|c|c|c|c|c|}
\hline \multirow{2}{*}{ NO } & \multirow{2}{*}{$\begin{array}{l}\text { INDIKATOR VARIABEL } \\
\text { keberangkatan }\end{array}$} & \multicolumn{2}{|c|}{ NILAI TOTAL } & \multirow{2}{*}{$\mathrm{X}_{\mathrm{i}}$} & \multirow{2}{*}{$Y_{i}$} & \multirow{2}{*}{$\begin{array}{l}\mathrm{TKi} \\
(\%)\end{array}$} & \multirow{2}{*}{ GAP } \\
\hline & & KEPUASAN & KEPENTINGAN & & & & \\
\hline 8 & $\begin{array}{l}\text { Ketersediaan fasilitas khusus dan } \\
\text { toilet khusus penyandang difabel \& } \\
\text { lansia }\end{array}$ & 787 & 1253 & 7.87 & 12.53 & 62.8 & -4.66 \\
\hline 9 & $\begin{array}{l}\text { Ketersediaan fasilitas khusus ruang } \\
\text { ibu menyusui }\end{array}$ & 556 & 1270 & 5.56 & 12.7 & 43.8 & -7.14 \\
\hline 10 & $\begin{array}{c}\text { Kebersihan toilet di Terminal } \\
\text { Tawang Alun }\end{array}$ & 810 & 1227 & 8.10 & 12.27 & 66.0 & -4.17 \\
\hline 11 & $\begin{array}{c}\text { Kebersihan Tempat peribadatan } \\
\text { di Terminal Tawang Alun }\end{array}$ & 899 & 1239 & 8.99 & 12.39 & 72.6 & -3.40 \\
\hline 12 & $\begin{array}{c}\text { Tersedia Informasi Pelayanan yang } \\
\text { lengkap }\end{array}$ & 683 & 1277 & 6.82 & 12.77 & 53.4 & -5.95 \\
\hline & RATA - RATA & & & & & & -4.483 \\
\hline
\end{tabular}

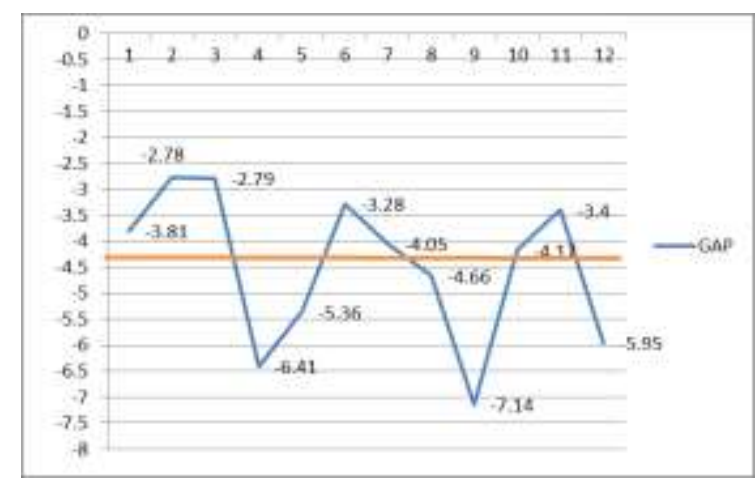

Gambar 2. Hasil analisis tingkat kesenjangan

Berdasarkan Gambar 2 didapatkan 5 indikator yang berada dibawah garis rata - rata nilai gap $(-4,483)$. Hal tersebut menjelaskan bahwa terdapat kesenjangan yang cukup tinggi antara kepuasan dan tingkat harapan dari pelanggan tentang fasilitas - fasilitas yang ada di terminal Tawang Alun.. Nilai kesenjangan paling tinggi adalah indikator atau fasilitas ketersediaan ruang ibu menyusui (-7.14), yang mana belum tersedia di terminal Tawang Alun.

\subsection{Importance Performance Analysis (Analisis Kuadran)}

Nilai total tingkat kepuasan dan kepentingan seperti yang dijelaskan pada Tabel 4. Kemudian dibagi dengan total responden sebanyak 390 responden. Dari pembagian tersebut didapatkan nilai rata - rata kepuasan dan kepentingan tiap - tiap indikator. Nilai tersebut di plot kedalam diagram kartesius dengan bantuan program analisis statistik. Dalam diagram tersebut menggambarkan pemetaan tiap indikator, sehingga didapatkan saran yang bisa menjadi rekomendasi bagi pengelola. Seperti yang digambarkan dalam Gambar 3.

Berdasarkan Gambar 3. Diatas didapatkan hasil sebagai berikut

1. Kuadran I (Concentrate Here)

Indikator yang berada dalam kuadran ini memiliki nilai tingkat harapan tinggi, namun tingkat kepuasan rendah, sehingga pengelola bisa memprioritaskan. Antara lain indikator 4 , indikator 5 , indikator 8 , indikator 9, dan indikator 12, merujuk pada Tabel 4.

2. Kuadran II (Keep Up With The Group Work) 
Indikator yang berada dalam kuadran ini memiliki nilai tingkat harapan tinggi, namun tingkat kepuasan tinggi, sehingga pengelola harus terus menjaga konsistensi kinerja pada kuadran ini. Antara lain indikator 1 dan indikator 7.

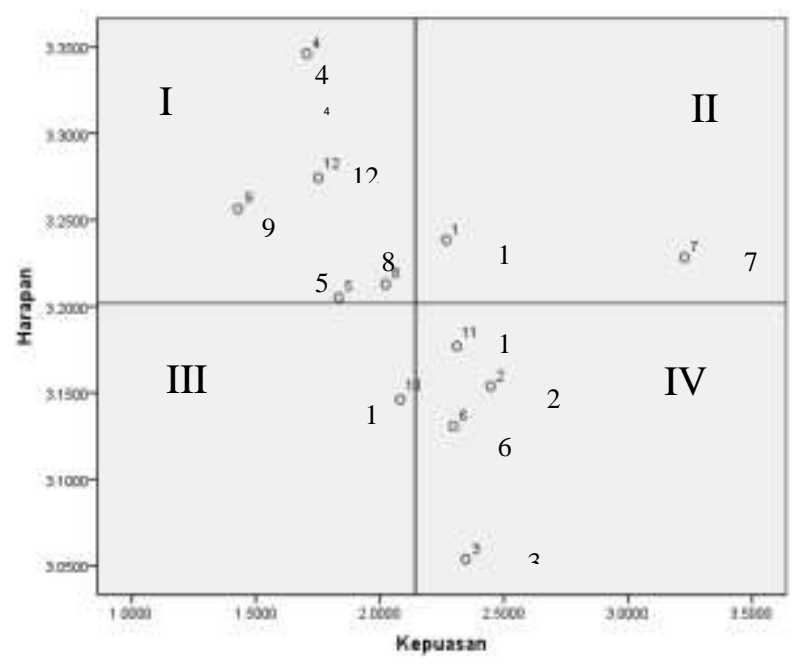

Gambar 3. Hasil analisis metode IPA dengan program bantu analisis statistik

\section{Kuadran III (Low Priority)}

Indikator yang berada dalam kuadran ini memiliki nilai tingkat harapan rendah, dan tingkat kepuasan juga rendah, sehingga pengelola harus meningkatkan kinerja pada kuadran ini. Sehingga bisa meningkatkan nilai tingkat kepuasan. Seperti indikator 10

4. Kuadaran IV (Possibly Overkill)

Indikator yang berada dalam kuadran ini memiliki nilai tingkat rendah, namun tingkat kepuasan tinggi, sehingga pengelola bisa mengolah sumber daya untuk dialihkan ke indikator yang membutuhkan perhatian khusus. Indikator yang masuk dalam kuadran ini antara lain indikator 2 , indikator 3, indikator 6 dan indikator 11 .

\section{KESIMPULAN DAN SARAN}

\subsection{Kesimpulan}

1. Berdasarkan hasil pengamatan kinerja fasilitas dan pelayanan di Terminal Tawang Alun, tingkat pelayanan adalah sebesar 50,00\% karena dari keseluruhan fasilitas yang ada, Terminal Tawang Alun hanya memenuhi 28 indikator dari total 56 indikator pelayanan yang terdapat dalam
SPM Peraturan Menteri Nomor 40 Tahun 2015.

2. Untuk tingkat kepuasan, unsur pelayanan di Terminal Tawang Alun bernilai 51,31 yang masuk dalam kategori nilai D (Tidak Baik). Nilai tingkat kepuasan tersebut kemudian digambarkan dengan Diagram Kartesius yang diperoleh dari hasil analisis kuadran menggunakan program bantu analisis statistik. Hasil penelitian juga menunjukkan selisih nilai gap paling besar terdapat pada fasilitas Ruang Khusus Ibu Menyusui $(-7,13)$.

\subsection{Saran}

1. Disarankan bisa membuat perencanaan ulang dari terminal Tawang Alun disesuaikan dengan standar yang berlaku

2. Disarankan penelitian selanjutnya memperhatikan pendistribusian responden, sehingga responden atau populasi dapat benar - benar mewakili tiap masing masing tujuan.

\section{DAFTAR PUSTAKA}

[1] Warpani, P. Suwardjoko, Pengelolaan Lalu Lintas dan Angkutan Jalan, Bandung : Penerbit ITB, 2002.

[2] Peraturan Daerah Kabupaten Jember No 1 Tahun 2015, Rencana Tata Ruang Wilayah Kabupaten Jember Tahun 2015 - 2035. Jember.

[3] Peraturan Menteri Pendayagunaan Aparatur Negara dan Reformasi Birokrasi Republik Indonesia Nomor 14 Tahun 2017, Pedoman Penyusunan Survei Kepuasan Masyarakat Unit Penyelenggara Pelayanan Publik, 9 Mei 2017, Jakarta.

[4] Brandt R. D., An 'outside-in' approach to determining customer-driven priorities for Improvement and Innovation. Burke White Paper Series, 2(2), $2000: 1-8$.

[5] Latu, T.M., Everett, A.M., Review of Satisfaction Research and Measurement Approaches, Departement of Conservation, Wellington, New Zealand, 2000.

[6] Peraturan Menteri Perhubungan Nomor 40 Tahun 2015, Standar Pelayanan Penyelenggaran Terminal Penumpang Angkutan Jalan, 23 Februari 2015, Jakarta.

[7] Kotler, Philip \& Keller, Kevin Lane, Manajemen Pemasaran, Edisi 13, Jilid satu, Erlangga : Jakarta, 2009.

[8] Martilla, J. A., \& James, J. C., Importance-performance analysis, Journal of Marketing, 41(1), 1977 : 77-79

[9] Supranto. J., Pengukuran Tingkat Kepuasan 
Pelanggan. Jakarta: Rineka ipta., 1997.

[10] Sugiyono, Metode Penelitian Pendidikan Pendekatan Kuantitatif, Kualitatif, dan $R \& D$, Bandung: Alfabeta, 2016.

[11] Umar, H., Riset Pemasaran dan Perilaku Konsumen, Jakarta: PT. Gramedia Pustaka Utama dengan Jakarta Business Research
Center, 2005.

[12] Ghozali, Imam., Aplikasi Analisis Multivariate Dengan Program SPSS, Edisi Keempat, Semarang: Badan Penerbit Universitas Diponegoro, 2009. 